\title{
The Spanish Counter-Enlightenment: an Overview, I774-I8I4
}

Carolina Armenteros

HCM 7: 504-537

DOI: $10.18352 / \mathrm{hcm} .569$

\begin{abstract}
At once neglected and deeply controversial, the Spanish CounterEnlightenment is crucial to understanding the development of Spanish politics and social thought until at least the mid-twentieth century. From Marcelino Menéndez Pelayo's praise to Javier Herrero's denigration to the more balanced assessments of present-day scholars, the movement continues to be a source of debate and varying evaluations. Still, key aspects of it remain to be known, including its anthropology, its approach to Enlightened political concepts, its inheritance from Salamanca scholastics and its ideas on interiority and the relationship between the individual and the state. This paper defines these aspects by examining the works of five of the Spanish Counter-Enlightenment's major representatives: Fernando de Ceballos y Mier, (I732-I802), Vicente Fernández de Valcarce (I723-98), Lorenzo Hervás y Panduro (I735-I809), Francisco Alvarado (I756-I8I4) and Rafael de Vélez ( I777-I 850). The first aim is to identify what made the Spanish CounterEnlightenment unique yet related to the French Counter-Enlightenment that nurtured and preceded it. The second aim is to provide a general overview of the movement even while introducing it to an Englishspeaking audience for the first time.
\end{abstract}

Keywords: anthropology, Cádiz Constitution, Cádiz Cortes, Enlightenment, Fernando de Ceballos y Mier, filósofo rancio, Francisco Alvarado, French Revolution, Javier Herrero, Lorenzo Hervás y Panduro, Marcelino Menéndez Pelayo, Peninsular War, 
Rafael de Vélez, Spanish Counter-Enlightenment, Spanish Inquisition, Vicente Fernández de Valcarce, War of the Pyrenees

\section{Introduction $^{\mathrm{I}}$}

Few subjects are as neglected as the Spanish Counter-Enlightenment, yet few are so relevant to Spanish political history. At least that is the argument of the book to this day considered the classic on the subject, Javier Herrero's Los orígenes del pensamiento reaccionario español (I97I). This work rebelled against the nationalist érudit who founded the history of Spanish literature, ${ }^{2}$ Marcelino Menéndez Pelayo (I 856I9I 2), whose own classic Los heterodoxos españoles (I880-2) extolled 'the old Spanish science' - what today we would call the CounterEnlightenment - as the most valuable part of eighteenth-century Spanish literature, a corpus comparatively neglected due to its stylistic defects and very solidity, but providing clear and logical answers to the theses of 'false philosophy', the label that Spain's militant clergy had reserved for Enlightened thought since the I770s.

Herrero subverted this thesis. Defining the Spanish CounterEnlightenment as inherently violent and annihilating, he evoked the 'fanatical, intolerant and aggressive spirituality' that spread through the 'continual and extremely passionate preaching' of the 'great mass of the clergy' as the key to the Spanish people's uprising during the Peninsular War and as 'one of the essential constants of the modern Spanish soul, precisely what we could call the rancid, ${ }^{3}$ castizo $^{4}$ or traditional element of our character'. ${ }^{5}$ Herrero refused to lend creative abilities to early conservatism, presenting it as a historiographic fraud, an intellectual scarecrow made of lies that could only wave medieval syllogism in the face of modernity, and that invented a paranoid myth about the international conspiracy of the 'sects', that is Calvinists, Protestants, Jansenists, libertines, materialists, Freemasons and philosophes. That eighteenth-century Spain was almost wholly ignorant of the European Enlightenment, due both to the lack of translations and the effectiveness of inquisitorial censorship, lends persuasion to Herrero's argument for a wholesale invention. The idea that early reactionary thought was itself ultimately modern also leaves Herrero unimpressed: he calls it the "traditional cry of all reactionaries' that uses the vocabulary of Enlightenment, liberty 
and equality to hide 'realities radically different from those that ... modern thought' designates by these words. ${ }^{6}$ The recurrent desire of the less ill-disposed reader is that Herrero might define what, exactly, those 'realities radically different' might have been.

The comparatively few publications on Spanish antiliberal thought have criticised or surpassed Herrero on this point. ${ }^{7}$ In 2007, Julio Herrera, a philosopher with the same initials and a name quite similar to Herrero's, published a work entitled Serviles! El grupo reaccionario de las Cortes de Cádiz. The carefully conceived product of three decades of archival work, Serviles! reconstructs the conservative group that formed at the Cádiz Cortes between I8Io and I8I4. Reviewing Los orígenes del pensamiento reaccionario español, Herrera objects that of the very long list of Counter-Enlighteners that Menéndez Pelayo discussed, Herrero chose only those who fit his thesis, and that far from being reducible to a collection of paranoid falsehoods about the 'sects', the Spanish Counter-Enlightenment represented 'a much richer tradition'. In his multiple articles on the subject, José Álvarez Junco describes this tradition as characterized by a distancing from Salamanca scholastics, a rejection of European Counter-Enlightened arguments like Burke's ${ }^{9}$ (who denounced the French Revolution for being not impious but useless and dangerous) and a grounding of the Old Regime in the order of nature. ${ }^{10}$ More recently, Andoni Artola Renedo and Antonio Calvo Maturana have added that, during the two decades that preceded the meeting of the Cortes, the Spanish Counter-Enlightenment was marked by political and intellectual heterogeneity, especially in regard to the question of temporal power, with a shift from Jansenism to ultramontanism taking place across the French revolutionary divide. ${ }^{\text {II }}$

This essay builds on these works while presenting the Spanish Counter-Enlightenment to an English-speaking audience for the first time, and by reflecting on some of the movement's unexplored themes its anthropology, its approach to specific Enlightened political concepts, its inheritance from Salamanca scholastics and its ideas on interiority and the relationship between the individual and the state. To combine depth and breadth, I read closely, in political and biographical context, five major authors that represented the movement during the four decades of its existence, from its inception in the last quarter of the eighteenth century to the closing of the Cortes in I8I4. On occasion, I also compare Spanish Counter-Enlighteners to francophone ones, especially 
Joseph de Maistre (I753-I82 I), the latter's most noted representative. I do this because, as Herrero was the first to remark, the French CounterEnlightenment was the 'immensely influential' source of its European equivalents, so that reference to the francophone precedent is indispensable for providing a proper intellectual context. ${ }^{12}$ In addition, the French Revolution ( I789-99), the War of the Pyrenees ( $1793-5$ ) and the Peninsular War (I807-I4) all seemed to justify and confirm the fears that Spanish Counter-Enlighteners had expressed about French ideas during the decades that preceded the Revolution, rendering France ever relevant to understanding their thought and their compatriots.

The aim is not only to present a literature almost wholly unknown in the English-speaking world and comparatively little studied even in the Spanish one. It is also to understand the unique forms that Spanish politics and collective identity adopted down to the rise of National Catholicism in the twentieth century and the confrontation between the 'two Spains' during the Civil War of I936-9. It is, in short, to reflect on Spain's Sonderweg and its causes.

\section{The Godfather of the Spanish Counter-Enlightenment: Fernando de Ceballos}

If anyone has a right to be called the godfather of the Spanish CounterEnlightenment, it is Fernando de Ceballos y Mier (I732-I802), ${ }^{13}$ the hieronymite friar at the University of Seville and the Monastery of San Isidro del Campo who authored the seven-volume La falsa filosofía (I774-6) (Fig. I). For centuries, conservatives, counter-revolutionaries and Counter-Enlighteners used the title of this work to refer to progressive sensibilities in general and eighteenth-century philosophy in particular. Today, the book's contents may not immediately suggest its lasting influence. La falsa filosofía is an exercise in vituperation that denounces liberty, equality and national sovereignty as the fundamental follies of modern European thought, itself presented as a bestializing movement that began with Protestantism and culminated in the Enlightenment. The work is an 'arid desert ... full of horror' ${ }^{14}$ as the author himself describes it, a forceful and encyclopedic lamentation on philosophical calamities ancient and modern so gloomy and diffuse that even the usually crystal clear Menéndez Pelayo becomes murky in his description of it. ${ }^{15}$ Yet the text displays a plentiful erudition and is written in a pleasant style that 


\section{LA FALSA FILOSOFIA, \\ ò

EL ATEISMO , DEISMO, MATERIALISMO,

y demás nuevas Sectas,

CONVENCIDAS DE CRIMEN DE ESTADO contra los Soberanos y sus regalí.ts, contra los Magistrados' y Potestades legitimas.

\section{LIBR O PRIMER O.}

DONDE SE COMBATEN LAS VANAS HYPOTESIS

y Principios sediciosos de los Ateistas, Deistas,

Fatalistas, Naturalistas, y demás pretendidos ..

Filósofos.

\section{T OMO SEGUNDO.}

\section{SU AUTOR}

FR. FER NANDO DE ZZEVALLOS, Monge Geronymo del Monasterio de San Isidro del Campo.

\section{$\frac{\text { SEGUNDA IMPRESION. }}{\text { Et nunc Reges intelligite : Erudimini qui judicatis terram. Patup. } 2 .}$ t. 10 .}

CON PRIVILEGIO

\section{EN M A D R I D.}

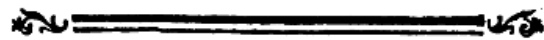

En la Imprenta de Antonio Fremandez. Año de 1775.

Figure I. Cover of Ceballos' La falsa filosofía, first edition, second volume, second reprinting (1775). Source: Wikimedia Commons. ${ }^{\mathrm{I}}$

help explain its author's continuing influence for over a century. As late as I878, León Carbonero y Sol (I8I2-I902), the professor of Arabic at the University of Seville, was printing Ceballo's unpublished manuscripts in his integrist newspaper $\mathrm{La} \mathrm{Cruz.}{ }^{16}$ 
Ceballos' influence was however wavering, and tied to his expression of views pleasing to the government. With foresight, he dedicated La falsa filosofía to Pedro Rodríguez de Campomanes (I723-I802), Carlos III's enlightened Minister of Hacienda. ${ }^{18}$ The strangeness of this alliance is highlighted when remembering that Campomanes was not only an Enlightener but also a Jansenist and the author of a treatise on the government's right to limit the expansion of ecclesiastical property. ${ }^{19}$ Whether out of principle or expediency, Ceballos ignored these details, and though in La falsa filosofía he called Jansenism a bane, he also strongly supported regalias like a good Spanish Jansenist. The French Revolution, however, would soon persuade him to abandon these views, as it would the majority of Europe's Catholic clergy, so that in later decades, when the clergy's property and very survival were at stake, Ceballos continued to uphold the monarchy, but this time with the tone of a devoted ultramontanist ${ }^{20}$ who praised effusively Madame Réal as 'the most heroic example of friendship, that was dreamt of in the world, that was sung in fables, or was referred to in history'. ${ }^{21}$

For the first six volumes of La falsa filosofía the odd entente between Counter-Enlightened friar and Enlightened Jansenist minister continued harmoniously, until the former decided to include among his philosophic targets none other than Cesare Beccaria (I738-94), the author of Dei delitti e delle pene (I764). The humane prescriptions of this landmark work in cases of crimes against religion upset Ceballos, who advocated torture, capital punishment and the Inquisition's sanctions against unbelievers, and who was convinced that kings, as 'ministers of God', had an absolute right over the persons of their subjects. '[D]eath is no injury when it comes from the hand of the one who has graciously given us life', he wrote chillingly, and 'the same must be said of anyone else who in the name of God and by his orders takes away the life of certain men, even when on the part of these last there were no guilt' ${ }^{22}$ For maintaining the contrary Ceballos qualified Beccaria as a 'public prevaricator' and a 'colleague of evil people' among other, more offensive epithets.

Such spite did not pass unnoticed. In I775 Juan Antonio de Las Casas, the translator of Dei delitti, ${ }^{23}$ wrote to the Consejo de Castilla led by Campomanes to complain about the 'deluge of expletives and decomposed expressions' that flowed from Ceballos' pen against Beccaria, ${ }^{24}$ whose masterpiece Campomanes himself had approved. 
After a long deliberation, and despite the Inquisition's banning of Dei delitti in I777, the Council decided to condemn Ceballos to 'perpetual silence' in $\mathrm{I} 778,{ }^{25}$ and it did so so effectively that to this day the seventh volume of La falsa filosofía exists only in manuscript form. There understandably followed a nadir of public attention to the work, but by I802, when confidence in the government of Carlos IV had plummeted, interest in Ceballos' opus revitalized and what rare copies remained of it were being sold at 'very expensive' prices. ${ }^{26}$

The Consejo's decision must have left Ceballos feeling that the government did not know its own interests, since even more than defend religion, the avowed purpose of La falsa filosofía was to defend the state. One must concede that discerning the threat that Enlightenment philosophy posed to the political structures of the Old Regime required unusually high discernment in the mid-I770s, more than two decades before the French Revolution and in a country almost wholly ignorant of the Enlightenment as was Spain. La falsa filosofía's very title indicates that it seeks to 'convict' 'atheism, deism, materialism, and the other new Sects', of 'crimes against the State' affecting 'Sovereigns and their regalia', and 'Magistrates and their legitimate Powers'. Admittedly, the reason for adopting this approach was purely argumentative. 'Such is the disposition of the majority of men in these times!', Ceballos exclaimed elegiacally, 'that although they call themselves Christian, they give more consideration to temporal things, than to eternal ones' ${ }^{27}$ And because those who professed the 'false philosophy' would 'rather glorify and pride themselves for having shaken off Christianity's yoke', arguing against them successfully entailed not proving that they were sinners, but rather

public convicts of all laws, and of every crime of State [...] rebels against Kings, Magistrates, and all the Power ordained by God: who by the principles of their systems try to dissipate all society and all established government, even the economy, and peace of families: finally, that they are the common enemies of humanity, and tend to destroy it from the birth of men to suicide. ${ }^{28}$

The government should hence be the first to silence the 'false philosophers'. It is 'an Axiom of good politics', Ceballos wrote, 'that one never touches the fundaments of Religion, without shaking those of the 
Region', ${ }^{29}$ and that the 'rights of the Kingdom and of the Citizens' had to be 'conserved', as among the Romans, by the 'old customs and the Religion of the fatherland'. For Ceballos, 'philosophy ceases so being, if it does not contribute to all the goods of society', ${ }^{30}$ and 'true philosophy' is the one that not only Christian thinkers, but also Cicero and Seneca described, the one that 'render[s] its first offices to Religion, and at the feet of the altars'.$^{31}$

If 'true philosophy' in its highest, Catholic form were instituted, Ceballos assured, the state would have at its disposal '[c]itizens perfectly united by a love all celestial' and not by the philosophers' 'amourpropre, or [love] of oneself'; [c]itizens 'not dissolute and worldly' like philosophic citizens, but guided 'by noble goals, and sworn to the good of society'. In a word, 'Citizens of the Saints, ${ }^{32}$ as St. Paul calls them', ${ }^{33}$ With such people one could build a utopia resembling the cities that Cicero applauded ancient philosophy for creating, communities where 'a docile people [was] submissive to all fathers, as much of the fatherland, as of families' ${ }^{34}$ Like pre-modern thinkers - and like Robert Filmer (I588-I653) and Jacques Bénigne Bossuet (I627-I704) Ceballos thinks of the State as a 'great family', and believes that the same Christian virtues that make families happy also render states prosperous.

Yet 'love all celestial' cannot create social happiness on its own, for, the friar asks, 'who can satisfy a people where dictates and interests are irreconcilable?'. 'Each person thinks in a different way.' 35 To Ceballos' mind, intellectual diversity suffocated 'love all celestial' and created the need for fear. That is why he thought that the Spanish universities of his time were in a 'dangerous state' requiring a 'permanent solution' (a disquieting harbinger of the way this phrase would be used in the twentieth century); and why in I794-6 he started a correspondence with yet another enlightened prime minister, Carlos IV's Manuel Godoy (I767-I85I), whose correspondence with the friar despite the disparity of views signals the eighteenth-century Spanish monarchy's ultimate dependence on the clergy's good will. In his letter, Ceballos outlined a plan for the universities, especially Salamanca, and proposed that they be placed under a Consejo or Dirección General de Estudios composed exclusively of members of the regular clergy ${ }^{36}-$ an institution that would presumably replicate for the universities the Jesuit Junta de Colegios that presided over Spain's most prestigious colleges. ${ }^{37}$ The 
plan was never implemented, but if it had, it would have homogenized Spanish intellectual life, yet without diminishing the study of letters, as perhaps unexpectedly for someone who thought they could be so pernicious, Ceballos assigned them a critical role in public life, writing that weighty judgments like war and peace should be considered by both generals and men of letters. ${ }^{3}$

Still, not all letters were equal. Ceballos appreciated fact over imagination and history over poetry. The second volume of La falsa filosofía associates poets with 'barbarians', and huffs that deists prefer 'a poet to a prophet; fables to the Gospel' and 'whatever other witness' to an eyewitness. Such views were typical as well of francophone CounterEnlighteners, who in defending Christianity defended a historical religion, and who in assailing poets sought to dishonour the pagan fables that had inspired the philosophes. History as the art of truth and the source of 'true philosophy' was a staple theme of the Counter-Enlightenment, and in matters of knowledge Ceballos practiced what he preached. One probable reason that La falsa filosofía appealed to contemporaries was the solid erudition and the multitude of curious facts, ancient and modern, that it contained: from the ancient Spartans' exclusion of libertines from common meals and games ${ }^{39}$ to Voltaire's letter to Dom Calmet asking to become a Benedictine for a few days ${ }^{40}$ to the Origenist leanings of sixteenth- and seventeenth-century Calvinists. ${ }^{4 \mathrm{I}}$ Ceballos attended as well to non-Western, mostly ancient, cultures. The second volume of La falsa filosofía provides information on Chinese cosmology, Persian religion, Phoenician physics, ancient Egyptian culture, Chaldean theories of nature, Babylonian astrology and the beliefs of Mississippi and Louisiana Indians. With the exception of Africa, India, Oceania and the European Middle Ages, he invokes all the world's historical times and regions.

This universal and encyclopedic historical approach underlay what Richard Herr called Ceballos' most impressive endeavour: ${ }^{42}$ his attempt to trace the enemies of his century - deists, atheists, Pyrrhonists, esprits forts, Freemasons (whom he conflated with libertines ${ }^{43}$ ) - all the way back to Cain. These impious and incredulous groups, Ceballos believed, had thrived through human history, but never in such diversity or with such destructive intensity as in his own time. Thus though the ancients were hardly faultless - the friar found no humility among the pagans, discerned hypocrisy in their famed sobriety, and blamed them 
for planting the original seed of evil - he still preferred them to the moderns.

This becomes clear when, taking up a genre that had been popular in the previous century, he emulates Lucian's Dialogues of the Dead in the posthumous tale El Juicio final de Voltaire (I 856), whose narrator travels toward Lemnos in a ship full of Voltaire idolaters that shipwrecks off the coast of Antiparos on learning that Voltaire has died. The author-castaway descends into a grotto that turns out to be the mouth of hell, where Voltaire is being dragged to be judged by some of antiquity's most eminent authors. After long discussions that review Voltaire's life and work and show the virtues of ancient pagan philosophy over the modern European variety, the judgment, of course, is condemnatory. The story shows that if in seventeenth-century France, the moderns won the quarrel between the ancients and the moderns, a century later the ancients were carrying home the prize among Spain's CounterEnlighteners. It was a sign of things to come.

\section{The Spiritual Conservative: Vicente Fernández de Valcarce}

A less combative and more spiritualist version of the Spanish CounterEnlightenment saw the light a decade after La falsa filosofía, when His Majesty's Chaplain Vicente Fernández de Valcarce (I723-98), regarding whom little is known other than that he was a canon at the cathedral of Palencia, ${ }^{44}$ began publishing Desengaños filosóficos (Fig. 2). The first three volumes were written before the French Revolution and appeared in 1787-90. They critique contemporary ideas on subjects with theological implications like miraculous cures, the subtle body, the plurality of worlds, the planets' population and the date of the end of the world, which Valcarce believed humans could not determine. The canon criticised Bayle, Locke and Malebranche among many other moderns, especially Descartes, whose scepticism he blamed for destroying the pax scholastica that had once reigned over European letters. But he was especially fond of Montaigne, whom he cited abundantly to support his points, and though he censured Leibniz he also called him to his aid. Seneca and Augustine were also ancient favorites that disclosed his austere preferences. 


\section{$R 22^{55} \quad 55-1-14$ \\ DESENGAÑOS FILOSÓFICOS, \\ QUE EN OBSEQUIO \\ DE L A VER D A D, \\ DE L A R E I G I O N, \\ Y DE LA PATRIA, \\ DÁ AL PÚBLICO \\ EL DOCTOR DON VICENTE FERNANDEZ \\ VALCARCE, CAPELLAN DB HONOR DB S. $\mathrm{M}$. \\ Y CANONIGO DE LA SANTA IGLESIA \\ dB PALBNCIA, \&C.}

Interrogate de semitis antiquis, qua sit via bona, \& ambulate in ea. J BREM. $6 . \mathrm{v} 16$.

\section{TOMO TERCERO.}

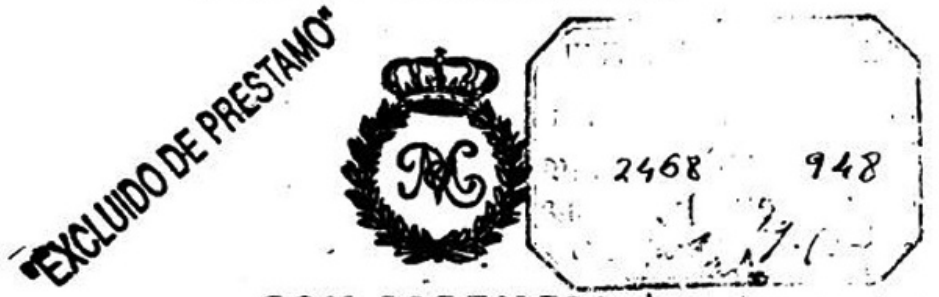

CON LICENCIA

EN MADRID. AÑO DE M.DCC.XC.

POR DON BLAS ROMAN,

IMPRESOR DE LA REAL ACADEMIA DE DERECHO ESPAÑOL

Y PUBLICO.

Figure 2. Title page of first edition of Desengaños filosóficos (I787). Source: HathiTrust. ${ }^{45}$

Desengaños fourth volume, published in I797, struck a new note. By then, both the French Revolution and the War of the Pyrenees (I793-5) had happened, and Valcarce had gained a new awareness of the importance of politics, that 'divinity that the world adores' ${ }^{46}$ It 
was an importance deplorable from his point of view, as the instability it introduced went hand in hand with state-builders' indifference to mores:

It has been some time since we lost the names of things, and for this reason the Republic finds itself in great danger [...] The happiness of the state is today called population, wealth, the conquest of new dominions, it is not counted with good mores, there must be many inhabitants, whether they are good, whether they are bad, it does not matter. Whether the acquisitions are just or not, once they are done, we have happiness.

If the revolutionary state preferred numbers and material wealth over the quality of social life, it also failed at maintaining order, that basic function of any government. '[O]rder, subordination and reverence toward the Powers as much ecclesiastical as secular, which until now had been regarded as the fundamental principle of public tranquillity, of government and good customs', Valcarce wrote, 'is today called slavery and baseness, dejection and miserable ignorance of the rights and prerogatives of the human race', ${ }^{4}$

The fact that these principles were now criticized in the name of reason furthermore meant for Valcarce that reason's name was among those lost. Echoing more calmly Ceballos' bestialization theme, he observed: 'A philosopher who places happiness in bodily pleasure, without doubt regulates all things by his senses, not by reason' ${ }^{48}$ The result was the decaying of reason: '[r]eforming reason and gathering its dictates without error, is a very difficult business in a time when madness predominates' ${ }^{49}$ Therefore, and since 'no providence is more effective' than 'intolerance, severity and rigor against all innovators', Valcarce appealed - as would all Spanish Counter-Enlighteners - to the Inquisition as the time-tested means of establishing reason.

Yet if fear could stifle the new philosophy, it could create no alternative to it. Like Ceballos, Valcarce proposed spiritual love as the key to social integration, but less interested than his predecessor in political authority, he focused instead on the individual's inner well-being. For Valcarce communal practices had to be conserved because collective worship edifies the soul, and understanding religious chants as Enlighteners required is unneeded because 'the affection, and piety, that is there exercised, and the general intention of gifting the Lord with 
those chants in the sense, and according to the intelligence, that the Church secretly holds, this is sufficient to reap the fruit'.$^{50}$ Like other Counter-Enlighteners (notably Rousseau ${ }^{5 \mathrm{I}}$ and Maistre) Valcarce points to the limitations of reason-as-logic (or reason-as-intellect) and evokes the deeper wisdom seated in love and devotion. Rather than paralyze reason, he argues, sacred mysteries stimulate sweet feelings. The secret to good politics is hence not to uphold rights, gather wealth, carry out conquests and demolish hierarchies. It is to generate happiness by stimulating feelings of piety, affection and gratitude.

\section{The Indignant Philologer: Lorenzo Hervás y Panduro}

As Valcarce wrote, the Spanish Counter-Enlightenment's most erudite and prolific author had already composed his sole counter-revolutionary opus. Although it would be published only in I803, Lorenzo Hervás y Panduro (I735-I809)'s Causas de la Revolución francesa had been in circulation since I795. A Jesuit polygraph who moved to Rome when Carlos III expelled the Society of Jesus from Spain in I767, Hervás was one of his age's most distinguished and prolific philologers (Fig. 3). Today, he is still known in the Spanish-speaking world as the father of comparative linguistics for discovering the Austronesian language family and for scientifically demonstrating the existence of the IndoEuropean family twenty-five years before Franz Bopp (I79I-I867). Hervás enjoys a good reputation in Italy too: he published widely in Italian, and Pius VII named him Director of the Pontifical Library at the Palazzo del Quirinale. Even Herrero calls Causas a 'work of astounding erudition'..$^{52}$

In I792 Hervás wrote to the Duke of Montemar (I757-I826), ${ }^{54}$ his former student at Madrid's Seminario de Nobles and his unconditional friend and indefatigable lifelong protector, attacking liberty and equality as the French Revolution's false philosophical foundations. ${ }^{55}$ Again, Ceballos had already set the precedent when condemning liberty, equality and national sovereignty in I774. But Causas was directly born out of Hervás' I794 correspondence with Tomás Bernad (I727-I806), Councilor of Castile, who informed him that Jansenism had become rooted in Spain and advised him to write on the French Revolution. A passionate defender of his order who blamed its dissolution on the 


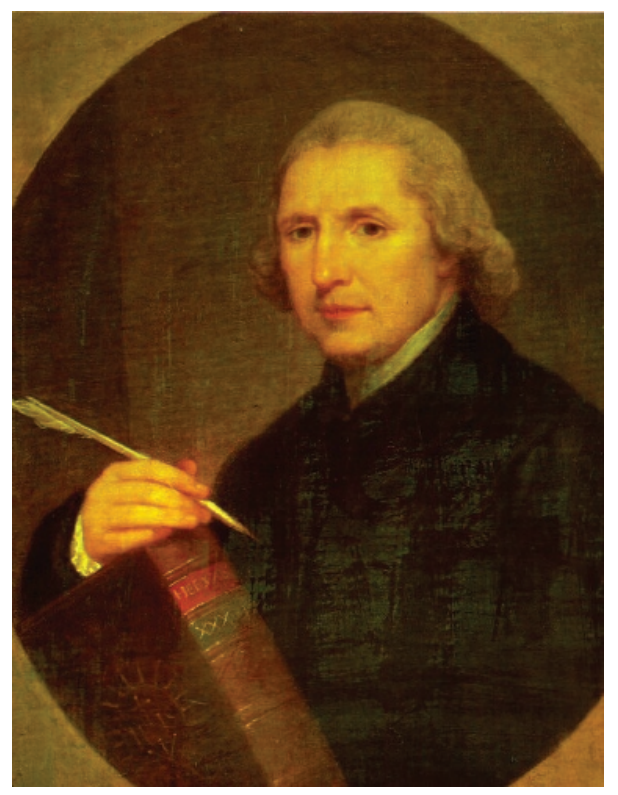

Figure 3. Lorenzo Hervás y Panduro (1735-1809). Portrait by Angelica Kauffman (I74I-1807). Source: Wikimedia Commons. ${ }^{53}$ Photograph by José Gabriel Storch de Gracia y Asensio, 2003.

Jansenists, Hervás immediately left everything aside, wrote a thousand pages in forty days, and sent them to Madrid..$^{56}$ At first, the work could not appear due to its fierce attack on Jansenism, which in Spain, unlike France, was a royalist movement. After I795, with the War of the Pyrenees concluded, Causas could still not be published due to Spain's new friendship with the French Republic. The book therefore began circulating in manuscript, until in $\mathrm{I} 803$ the daring conservative Baltasar Calvo (dates unknown) defied the prohibition and published it in Madrid unbeknownst to Hervás. Fortunately for both men, the queen and Godoy read it and were 'very pleased' with it. ${ }^{57}$

It is Causas that places Hervás squarely in the Counter-Enlightened tradition, as his scholarship is otherwise considered Enlightened: there is even a study of him entitled Lorenzo Hervás: ilustrado español (1988). ${ }^{58}$ True to the Spanish traditionalist tendency to blame 'sects' for modern horrors, Causas identifies the French Revolution's 'principal and most active causes' in the Calvinist, Jansenist, Freemasonic and philosophic 'sects' that, its author assures, had conspired secretly for 
centuries before the Revolution exploded. In general, Hervás seems all too eager to believe spurious anecdotes and documents, but his 'demonstration' of the sects' causation of the French Revolution is extremely erudite and not entirely fanciful, insofar as it establishes the widely accepted claim that Protestantism and philosophy prepared the French Revolution. Though its Manichaean and conspiratorial hermeneutics deprives it of status as serious history - unlike Hervás' other, quite solid scholarly contributions - Causas, especially in its first fifth, provides valuable insights into its author's social, religious and political ideals. Scholars interested in the political and ecclesiastical gossip of the revolutionary years will also find it a goldmine.

Akin to the French counter-revolutionaries Maistre and Louis de Bonald (1754-1840), who comment on France's European premiership, Hervás notes that before the Revolution, France was Europe's 'worldly idol'. However during the Revolution the country fell into such continent-wide ill repute that French émigré clerics had to remove the insignia that identified them as French in order to be well received abroad. From wise, France turned malignantly scientific, and from civil, it became ferocious. ${ }^{59}$ The base animality it now exhibited was that of the apocalyptic Beast. ${ }^{60}$ Ceballos' theme of bestialization recurs. France had become a tyranny governed by slaves. ${ }^{61}$ This was due to the Convention's destruction of religion, since human society could not survive without it, as Plutarch and Cicero had averred ${ }^{62}$ From the mud flowers grow, though, and the fruit of bestiality is saintly and heroic virtue. Ceballos' (and Joseph de Maistre's) praise of Madame Réal reappears in Hervás. Now, however, it accompanies that of the king's aunts and his Carmelite sister Louise of France, and it is followed by a long account of the French clergy's Christian heroics during the revolutionary years.

The profusion of revolutionary misfortunes was itself caused, Hervás affirms, by the "sects" spirit of liberty. 'The human Heart leans too much toward independence', he grieves, 'so that it is always disposed to protect the novelties that flatter' this disposition. ${ }^{63}$ Disaster has resulted: 'The people enchanted with chimeric equality and liberty have shaken off the brake of religion, that had them dependent on the laws, and have abandoned all the principles of natural reason.' The casualties of revolutionary principles are authority, fidelity, true freedom, religion and the natural reason central to the Spanish scholastic tradition. Once 
natural reason vanishes along with religion, civil society dissolves, since, as most Counter-Enlighteners insist, no society can exist without religion, and in fact even 'a public sect' of atheists is impossible. ${ }^{64}$

Indeed for Hervás the fundamental cause of France's disorders is the irreligious spirit it has harboured since pagan antiquity, when Cicero wrote that the Franks made war against all religions. ${ }^{65}$ By contrast, the Spanish according to Justin preferred death to unfaithfulness. ${ }^{66}$ Such arguments are understandable flowing from a conservative Spanish pen in the wake of the French betrayal of Spain that sparked the War of the Pyrenees. More fundamentally, the idea that religion influences national character and determines nations' political success shows us Hervás fostering the religiosity that Scott Eastman has described forging Spanish national identity even in the early nineteenth century, ${ }^{67}$ and that Álvarez Junco sees developing during later decades to attain its intellectual height with Menéndez Pelayo.

Hervás' deep concern, however, was not national identity but universal anthropology. Where francophone Counter-Enlighteners subordinated the moral to the political, the Spanish ones tended to dismiss the political altogether in favor of an anthropological vision of man's relationship with the cosmos. This suggests that, in seeking to define the rapport between humanity and nature, the Spanish CounterEnlightenment transformed rather than neglected the Salamancan natural law tradition, and that it did so in a manner that replicated the francophone Counter-Enlightenment's own transformation of natural law. ${ }^{68}$ Not in vain was Hervás' major work the massive Idea dell'Universo (I778-92), composed of no less than twenty-one volumes. And not idly did he devote four more tomes to mystical-cosmic themes: Virilità dell'Uomo (I779-1780), Vecchiaia e morte dell'Uomo (1780), Viaggio estatico al mondo planetario (I780) and Storia della Terra (I78I-3). As we shall see, anthropological mysticism would recur in the work of his Counter-Enlightened colleagues.

\section{The 'Rancid Philosopher': Francisco Alvarado}

If Joseph de Maistre has a Spanish twin, it is Francisco Alvarado (I756-I8I4) (Fig. 4). ${ }^{69}$ Nearly the same age, the two men coincided in exalting the Inquisition and attacking Jansenism, Protestantism, 


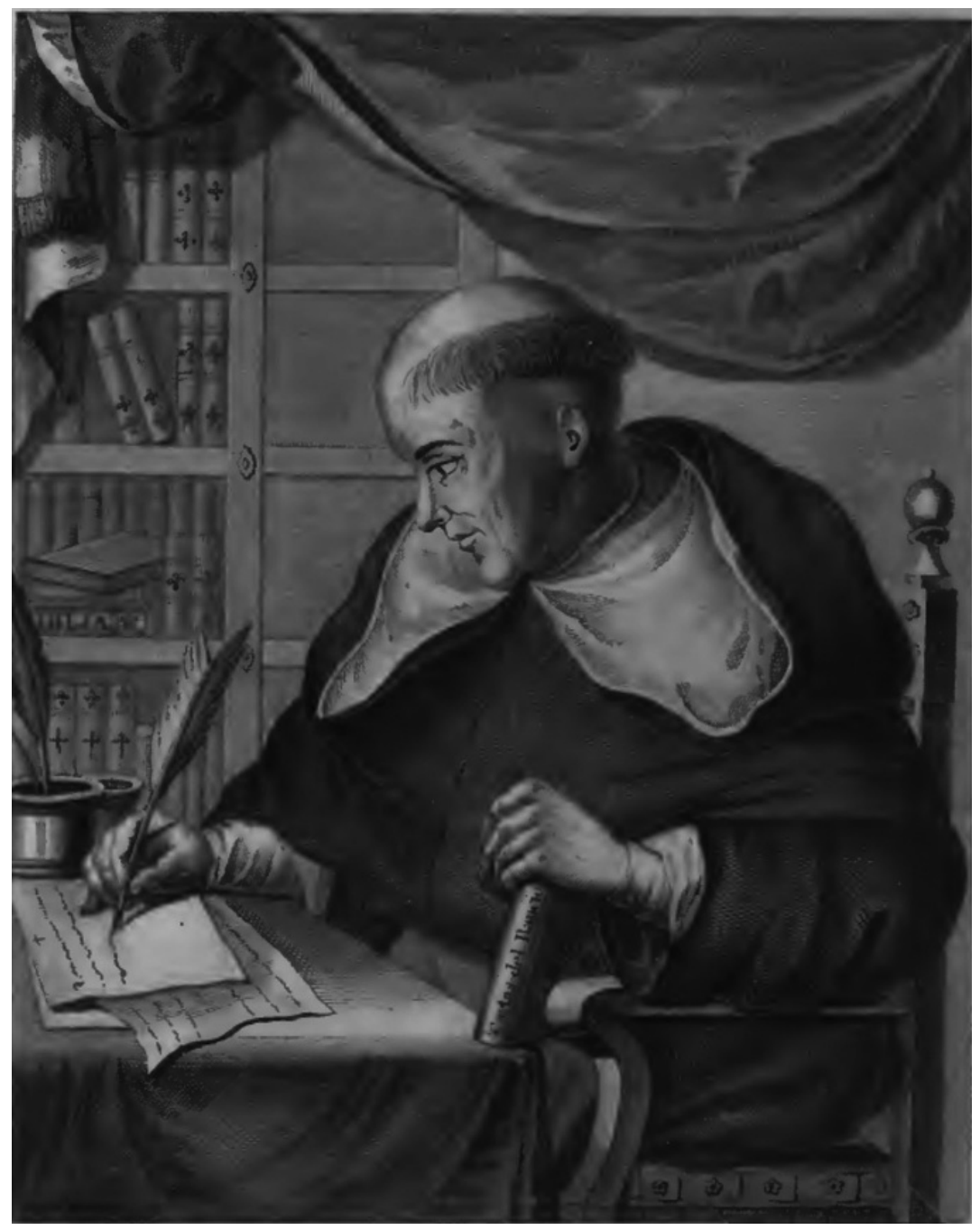

Figure 4. Francisco Alvarado, the 'rancid philosopher' (I756-I8I4). Source: Art Collection 4 / Alamy Stock Photo.

modern philosophy, the Encyclopédie and the French Revolution. They also became politically influential as exiles who composed stylistically masterful writings: Maistre the Savoyard in St. Petersburg, and Alvarado the Sevillian in Tavira. This frail and ill Dominican known for his ironic wit and kind temperament was dubbed 'el filósofo rancio' 
or 'the rancid philosopher' by the liberals for his conservative views. To this day his nickname is more widely employed than his name, not least because Alvarado readily embraced it, signing his famous letters with it. The friar also used joyfully the liberals' denigrating label for the Cortes' conservatives, 'serviles' - a play on the Spanish for 'the servile ones', a word that can be maliciously divided into 'ser' and 'viles', or 'be' and 'vile'.

Alvarado is remembered chiefly as the author of the Cartas criticas, a collection of letters expedited to friends in Cádiz between I 808 and I 8 I4, at first from exile in Tavira and later after returning to a liberated Seville. Herrera has shown that the recipients constituted a network of friends that the friar built during his extremely active life as student and professor in Seville's Convent of San Pablo and Colegio Mayor de Santo Tomás - two of the best institutions of higher learning in eighteenth-century Spain. As well-educated members of the elite, Alvarado's friends ended up as deputies and members of the conservative group that formed in Cádiz during the convening of the famous Cortes, which had declared themselves Spain's 'Majesty' while Napoleon kept Carlos IV and the future Fernando VII imprisoned in Bayonne.

Alvarado's major correspondent was his friend, the theologian, orator and deputy Don Francisco de Sales Rodríguez de la Bárcena (I758?), who kept the friar informed of Cádiz political events at least on a monthly, and more usually on a weekly and bimonthly basis. One day in I8I I Bárcena decided on his own initiative to print anonymously one of Alvarado's letters in order to support a particularly battered conservative agenda. It was a great risk to take in a Cádiz dominated by the liberal Cortes, which brutally and repeatedly violated the opposition's freedom of speech. But it paid off. Graceful, erudite and entertaining, drawing on the art of the sermon and exhibiting a pleasant and ironic style trained on abundant reading of Cervantes, Alvarado's letter filled a gaping literary void in Cádiz's political world to become the voice of the muffled conservative minority. Most excitingly, it did what no one until then had dared to do: it attacked Agustín de Argüelles (I776I 844), dubbed 'el divino' for his oratory, the man who had until then reigned unchallenged over the liberals and the Cortes. In this sense, the publication of Alvarado's letter marked the birth of democracy in Spanish history. So great indeed was its success that it went through four editions in half a week, the last being sold at four times the original 
price. From then on there was no turning back: faced with a frenzied demand for more, Bárcena had to cut up Alvarado's letters to keep the publications going, as the sick and indigent friar, who had to gather his food in the fields of Tavira, could not, for all his political passion, write fast enough to feed the literary hunger of Cádiz's right-wing public.

So what, then, was the content of these letters so eagerly awaited? The first attacks the concept of the general will that, 'according to the journalist friends of Mr Arguielles', was embodied in the Cortes' law project against the tithe, which envisioned expropriating the church to support the war effort - the first in a long series of ultimately successful attempts to nationalize ecclesiastical assets, and the one political consequence of Enlightenment that Ceballos, with all his support of regalias, had not predicted in the I770s. 'I would like', wrote Alvarado in a demanding tone that no one until then had dared to adopt, 'that $\mathrm{Mr}$ Argüelles should explain to me how he means that it should be declared to be [exemplary of the] general will the contrary of the opinions that he himself calls generally received'. Like Counter-Enlighteners in all Catholic Europe, Alvarado was keenly aware of the sway that the church had over the vast majority of the population, and of the violence that would be required to break this sway. The Cortes' intrusion into people's conscience was politically extreme: 'Most rare has been the heretic', observed Alvarado nettled, 'who has had the courage to pretend, as Mr Argüelles pretends, that a profane assembly should be the one to decide where piety is and is not'.$^{70}$ It was true that bishops 'can and should dispose of the church's assets in the present necessity', ${ }^{71}$ yet one could not do so by trampling people's religious identifications. 'For the Church's assets to serve the fatherland's needs', noted Alvarado with characteristic clarity, 'it is the same thing whether the Cortes levy [these assets], or whether they exhort the Bishops to levy them: but for us to conduct ourselves like Catholics, it is not the same thing'. ${ }^{72}$

Such critiques did not amount to a political theory. As a religious conservative who believed that governments were providentially designed, Alvarado was concerned to criticise policy rather than elaborate concepts. His letters disclose a deep knowledge of scholastic logic, but he uses it to repel liberal thought rather than propose alternatives, which he assumes tradition already provides. Still, his I808 experience of a weeping Andalusian people rushing to kneel and kiss his habit and praise God for a friar's presence as he walked home to Seville from 
Tavira (and as he wept himself) convinced him of what the 'true general will' was..$^{73}$ Indeed the agreement on the 'essential Catholicity of the Spanish people' was so unanimous that even the liberals, many of whom were at best dubiously religious, wrote it into the Cádiz Constitution, ${ }^{74}$ otherwise the most advanced charter of its time. Article I 2 read: "the religion of the Spanish nation is and will be perpetually the Catholic, apostolic, one and true. The nation protects it with wise and just laws and prohibits the exercise of any other'.

For early conservatives like Alvarado, though, such formal recognitions of Spain's Catholic status were hardly enough in light of the administrative and intellectual elites' actual rapprochement to the French invaders. It was these elites who truly drew Alvarado's spite, though the insults he reserved for them were softer and more Cervantesque than those Ceballos had aimed at the 'false philosophers': '[L]ittle lawyers of sweet water', we read in the Cartas, 'ties, little officers, poor gentlemen, trapped rich men, repentant clergymen'. ${ }^{75}$ The malevolent sarcasm that these appellations disclose testify to the Spanish clergy's unpleasant realization that a new, rival class had arisen that aimed to replace them as producers of knowledge and guides of the people's conscience. They were of two kinds. There were those who became part of the new French administration, many of whom had been functionaries under Carlos III and Carlos IV. The rising right thought them opportunists - the infamous afrancesados $^{76}$ - and they certainly comprised fortune seekers. Yet on the whole they were Enlighteners who took seriously the Napoleonic project of regeneration and sought to maintain the country's institutions in place. ${ }^{77}$ Then there were the Cádiz liberals, who refused to submit to the invader but proceeded to implement French political principles by convoking the Cortes not on the traditional model of the estates, but on the principle of national sovereignty. ${ }^{78}$

We applaud national sovereignty and take it for granted today, but it is well to remember just how extraordinary it must have seemed to a large portion of the Spanish population in the early i80os. Here was a collective liberal concept founded on people rather than on God, appearing suddenly in one of Europe's most religious and traditional countries, and proposed as the foundation of a supreme national law that happened to be the 'most progressive constitution' in Europe ${ }^{79}$ as well as one of the earliest constitutions in world history. 'From where has appeared to us', asked a stunned Alvarado, writing as if of a ghost, 
'this nation from which sovereignty is now hung?'80 The answer was clearly France, and for the Counter-Enlighteners, the liberals' rapprochement to the French enemy, whether through intellectual borrowing or direct collaboration, was nothing short of a betrayal of the fatherland and of the Christendom it represented. To this was added the strong popular and religious resistance to French invasion that marked the War of the Pyrenees and the Peninsular War. Recent revisionist historiography has downplayed the popular religious element and emphasized the formal, international military one, at least in the case of the Peninsular War ${ }^{81}$ but the fact remains that the explosively subversive alliance of low clergy and populace to expel the invader on both occasions more than sufficed to create a powerful nationalist myth, effective well into the second half of the twentieth century, of the church as the nation's true bastion, and of the liberals as Spain's betrayers. Alvarado was one of its early exponents. He notes that the church persecuted and expropriated by the French could not be expected, unlike many liberals and Enlighteners, to submit to the Napoleonic regime. The church and the friars, he writes, are the worst for Napoleon 'because they do not lend themselves, and there is no hope that they might lend themselves to be his agents in the usurpation ... the clergy's great sin in Napoleon's eyes is the nation's Resistance to him'. ${ }^{82}$

Beyond betraying God and nation, though, the liberal programme is politically bankrupt according to Alvarado. 'Unhappy us!' the friar laments. 'One of our evils was the multitude of laws, and now the remedy that is given to us is to throw upon us other laws'. ${ }^{83}$ The friar denounces the inefficiency of the fledgling democracy that has succeeded the old regime. The Cortes have deposited the executive power in a Regency hopelessly overtasked,${ }^{84}$ and the judicial power in courts so exceedingly slow that they ensure the impunity of the few traitors discovered. ${ }^{85}$ Worse, the Cortes are despotic. It is not that Alvarado objects to democracy or the social pact per se, since he celebrates their rule within the religious orders to which he belongs. On the contrary, he points out that the Cortes' liberal democracy promotes unfreedom, along with despotism's obverse and necessary companion, anarchy. This is the tragic result of the Cortes' proclaiming themselves 'Majesty' in Carlos IV's absence ${ }^{86}$ and dismissing natural sovereign authority in the process. In the end, like Maistre, Hervás and other European Counter-Enlighteners, Alvarado objects not to liberty, but to the aspiration to equality that for him smothers liberty's true form. 
Alvarado's greatest convergence with his colleagues, however, is on the cure he proposes for the dual bane of anarchy and despotism: the Inquisition, which he upholds as a careful and humane tribunal against $L a$ Inquisición sin máscara (I8I I) of Natanael Jomtob - the pseudonym of the philologer and Hebraist Antonio Puigblanch ( I775-I840). It was probably this defense that inspired Fernando VII to name Alvarado Supreme Court Inquisitor, a post that the friar never occupied, as the disease that was already devastating his health during his years in Tavira finally killed him soon after the king returned, and before service of the fearsome tribunal could taint his person and his memory. Alvarado's defence of the Inquisition, however, was but one instance of his more general conviction that the common interest is best served by subordinating the political order to the spiritual. This meant of course that he upheld the clergy: the Cartas refute at length the severely anticlerical Diccionario critico-burlesco (I8I I) of the bibliographer Bartolomé José Gallardo (I776-I852).

But it was not just any clergy. Like Maistre and Hervás, 'el filósofo Rancio' was above all an ultramontanist: the second volume of the Cartas is devoted to criticizing Jansenism. In this respect Alvarado typified his times. By the early nineteenth century, in the face of the state's expropriation of church property, the Jansenist-like support of regalias that Ceballos had combined with a critique of Jansenism in the I770s no longer made sense to Spanish religious orders. For not only their property, but their very existence was at stake. As Alvarado devotedly put it when he finally disclosed his clerical identity to his audience: 'I am a friar. A friar, yes sir; [...] and poor, and sick, and not among those best freed among the friars; [...] but so happy to be so, that if I learn of a corner, even if it is the last in the world, where force does not impede it, a friar I must be, as a friar I must live, as a friar among friars I must

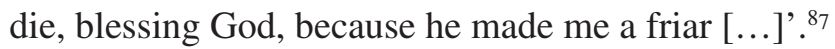

It is in this devotion to the spiritual life, more than in any political ideas, principles, reasons and convictions, that may be found the deep roots of early European conservatism, especially in its Spanish manifestation.

\section{The Committed Bishop: Rafael de Vélez}

There is perhaps no one, in the whole of the European CounterEnlightenment, who insisted more on the centrality of religion and 
spirituality than Rafael de Vélez (I777-I850), the combative Capuchin friar and indefatigable enemy of the Cádiz Constitution who sat as bishop of Ceuta, spent the Trienio Liberal in hiding, was later archbishop of Burgos and ended his life presiding Spain's most prestigious see, Santiago (Fig. 5). His work exhibits with the greatest force and clarity what makes the Spanish Counter-Enlightenment unique, namely, its full repudiation of both revolutionary ideas and Enlightened rationalism, ${ }^{88}$ along with an appeal not to theology, philosophy or political

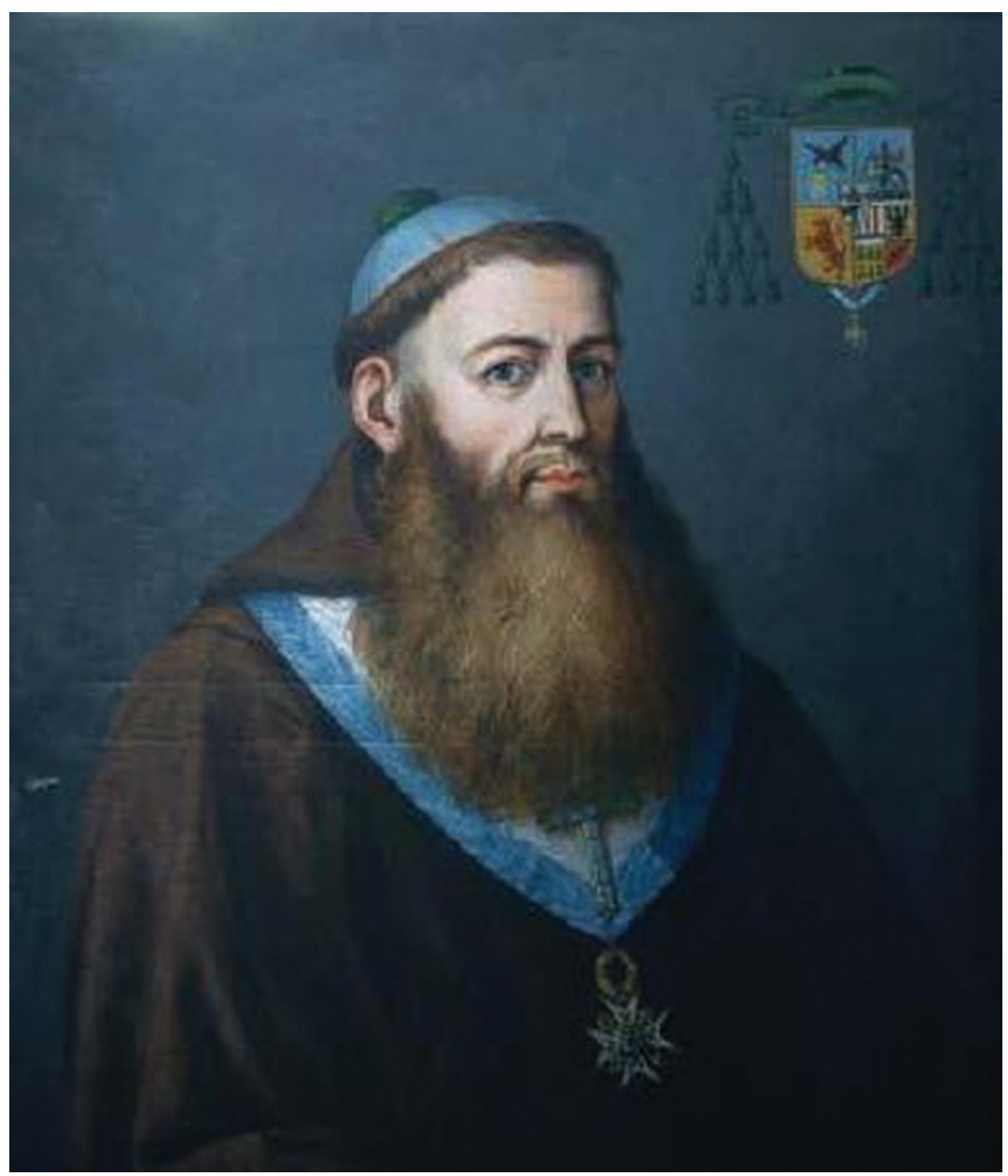

Figure 5. Rafael de Vélez. (I777-1850). Anonymous portrait, first half of the nineteenth century. Source: Wikimedia Commons. ${ }^{89}$ 
theory, but to the Old Regime's harmony with the natural order. These views made the Spanish thinkers even more reactionary than Maistre and Bonald, who in striving to prove the uses of monarchy and religion, still combated the Enlightenment on its own, chiefly political ground.

Vélez's unconditional repudiation of the Enlightenment explains why his two major works, the Preservativo contra la irreligión (I8I2) and the Apología del altar y del trono (I8I4), conduct a wholesale attack on all things French. The Preservativo was an attempt to prevent the spread of French philosophy as the war with France proceeded. The Apología, written upon Fernando VII's return from captivity, sought to eradicate all remains of that philosophy even after the war had been won. To this end, it denounced the Constitution of I8I 2 and the Cortes' reforms, including the abolition of the Inquisition, the expulsion of the papal nuncio, the reform of the canons regular and the project to confiscate church property.

For Vélez as for Alvarado, winning the war against Napoleon was useless 'if we admit [the tyrant's] enlightened ideas and his reforming plans'.$^{90}$ Like Hervás, the Capuchin saw Spain as purer than France, since only 'a very reduced number of Spaniards' had participated in the 'rebellion against the Church', and even in Spain the Enlightenment's reforming measures were more 'peaceful' than in France. ${ }^{91}$ Still, God had punished Spain, and the country would 'bear God's ire for some years' ${ }^{92}$ The key to appeasing this ire lay in recognizing that religion is 'the strongest link of society [and] the surest guarantee of all power', and that 'in its promises are exclusively fixed the citizen's worthy recompenses [and] the fair prizes of his honesty'. Where Hervás criticizes freedom as independence, Vélez instead affirms that for a citizen, 'the interests of his fatherland and his religion' 'are one and the same thing with the assets of his particular property'. ${ }^{93} \mathrm{He}$ envisions a fusion between individual, nation and church that seemingly exceeds the collectivism of any other Counter-Enlightener, Spanish or European, yet this is a fusion enabled not by good government, but by people's religious and patriotic feeling. The resulting subjectivism, similar to Valcarce's interiorism, is part and parcel of those constant themes of the Counter-Enlightenment that inspired the movement everywhere it arose: the superiority of interiority over exteriority, spiritual to material life, and religion over the state as the living breath of any political order. ${ }^{94}$ This in turn had a corollary in the precedence of monarch over 
nation, ${ }^{95}$ so that the key to national happiness lay not in reinventing the state, but in developing inner strength, itself admirably manifested through loyalty to disappointing governments. ${ }^{96}$

Before the "brilliant titles of liberty, equality and rights of the citizen' entered Spain, Vélez complains, the people were 'perfectly adhered to their king without daring to judge him even when they saw him as useless and criminal, as they believed that this exceeded their faculties'. Even more, Vélez continues nostalgically, they 'venerated their religion as the principal base of their individual happiness and of all the nation[; they] looked to the Inquisition as the secure wall and the firmest bulwark of throne and altar[; they] listened always submissive to the ministers of the sanctuary as to messengers of God and sole and faithful depositories of his divine word' ${ }^{97}$ It would be difficult to find, in the whole of Counter-Enlightened literature, an equally clear and naïve admission of the problem: in becoming open to new ideas, people had ceased submitting to traditional authority, to wit the clergy's.

Yet there is more to this nostalgia for perfect submission than a bishop's crude will to power. For Vélez, to obey is simply to apply Christian spirituality to politics: 'The need for faith the philosophers call tyranny; because faith must be submissive, humble, it must not seek reasons to believe, but [must believe] because God says so.$^{98}$ One reason that Vélez decries the 'empire of the constitution' is that under it, '[d]efending one's legitimate king, giving one's life for religion' cannot even be mentioned. ${ }^{99}$ Far more than a political order, what the Cádiz liberals are destroying is the human willingness to offer oneself for something experienced as greater than oneself. They are extinguishing, in short, the human capacity for devotion. If they succeed, this will have dire consequences, as devotion, both popular and royal, maintains the divine order. Vélez's Neoplatonism is evident. Yet even more exotically unmodern - indeed probably unrepeated in the whole of the European Counter-Enlightenment - is the passage that follows: 'The priest is ... the sole mediator between God and his people, the one who alone conserves the relations of heaven with the earth, of the creator with the creature, and of man with his God. Without this intimate union the universe would cease to exist'. ${ }^{\text {Ioo }}$

For Vélez, then, if the clergy disappears and God's ministers are no longer obeyed, if people lose their disposition to give their lives for God, not only will society and the world end, but the stars cease shining 
and the sea no longer roll to the shore. The existential role that this cosmic anthropology attributes to the clergy is one that Vélez himself was willing to defend unto great personal sacrifice. Thus in I820, when he was bishop of Ceuta and Francisco Isnardi (1750-ca. I820s), ${ }^{\text {Ior }}$ the secretary of the liberal governor Fernando Gómez de Butrón (I770I852), conducted a violent campaign against the church in Ceuta's first newspaper, El liberal africano, Vélez not only published an edict that was read in every church forbidding the reading of El liberal, but also refuted Isnardi with a pastoral so passionate that he was evicted from Ceuta. The silenced bishop would spend the remaining years of the Trienio Liberal ( $1820-3$ ) in hiding, erring from convent to convent - in Casares, Ubrique, Estepona - to avoid imprisonment. ${ }^{102}$ A decade later, when Fernando VII died and constitutionalism returned along with the confiscation of church property and the defrocking of the religious orders, Vélez was again exiled, this time to Menorca, where he spent a year indoors in an ultimately futile attempt to keep his religious habit. As with Alvarado, behind his writings raged the struggle to preserve a way of life - and its cosmic implications.

\section{Conclusion: The Difference the Inquisition Made}

That the Spanish Counter-Enlightenment ended with the clergy's struggle for survival is not a sign of its defeat: Catholic conservatism remained a vigorous, combative and frequently dominant political current in Spain well after the rise of National Catholicism in the twentieth century. The liberal attempt to eradicate the clergy is a sign of the Spanish Counter-Enlightenment's uniquely unmodern character (besides evincing, of course, the liberals' own wholesale adoption of French revolutionary anticlericalism). Most remarkable about the texts reviewed is their lack of engagement with contemporary philosophy. The founders of francophone conservatism had objected to Enlightened ideas, but in seeking to find their inner contradictions or use them to prove the advantages of religion they still incorporated them into their thought. The Spanish writers, by contrast, utterly lack any such engagement. Hervás defends natural reason and Alvarado and Vélez accept the social pact, yet even Alvarado criticizes the Cortes on scholastic grounds. Salamanca's natural law tradition, which they either neglected 
or transformed into a cosmic anthropology, was as close as these writers got to eighteenth-century philosophy. Their unconditional rejection of this philosophy further explains why their enemies tried to suppress them in turn.

Yet why always seek wholesale rejection? One might argue that the Franco-Spanish wars of the I790s and I80os created a repulsion for all things French, but while these conflicts certainly did not help, Ceballos was already attacking French thought indiscriminately in the I770s, when France and Spain were still allies. Nor can the problem be ascribed to lack of intelligence: Hervás and Alvarado possessed it in abundance, and even the exceedingly harsh Ceballos was an imaginative man with the capacity to write agreeably. The work of these men also supports knowledge and honours the Counter-Enlightened epistemology of the fact with solid and copious erudition. The problem seems to hinge, rather, on the one opinion that unites them all, before and after the French Revolution: that the Inquisition is the solution to all intellectual and political ills. The success and absoluteness with which this institution eliminated dissenting voices in Spain for over three centuries, and the hold it continued to have over Spanish consciences, meant that no compromise with, far less incorporation of, Enlightened and revolutionary ideas was even thinkable to those who lived under the 'monopoly of truth' it had created. ${ }^{103}$ As a result, the polarized politics that necessarily accompany the birth of modern democracy in a traditional religious society were possibly even more polarized in Spain than they had been in France. One can see this polarization continuing through the nineteenth century and contributing to the extreme left- and right-wing politics of the I930s that finally exploded in the Civil War of $1936-9,{ }^{104}$ a conflict motivated most fundamentally by the issue of religion, and ending with an autocratic government that supported the church and eliminated political difference just as the Inquisition before it had eliminated the religious variety.

Indeed religion, both in its spiritual-interior and its temporal-ecclesiastical expressions, was always the Counter-Enlightenment's deep motivation. The Cortes' designs on church assets were a decisive turning point: there is quite a distance from Ceballos' Jansenist-like support of regalias to Alvarado's ultramontanist defense of ecclesiastical property. On this point the Spaniards followed their francophone predecessors, whom the French Revolution's dechristianization campaigns 
had likewise thrown in the 'arms of the papacy'. ${ }^{105}$ The difference was that the Spaniards expressed the superiority of the church to the state with ingenuous clarity and directness, thoroughly convinced of its obviousness thanks to centuries of Inquisitorial assurances and monarchical submission to the clergy, while their francophone counterparts did so far more subtly and timidly. One has to read even the thundering Maistre with the utmost attention to realize that the rapport he posits between church and state is an unequal one. Not content, in fact, to subordinate the political to the religious, the Spanish writers dismissed the political altogether and replaced it with an anthropology that, though likewise elaborated by francophone Counter-Enlighteners like Maistre and Bonald, never reached the exhaustiveness that it did in Hervás, or expressed the need to live in loving harmony with church, nature, Creation and monarchy as directly as it did in Valcarce and Vélez. To this replacement of politics with anthropology as the key to human well-being was added a rejection of liberal democracy for suppressing what Hervás called 'true freedom' and for leading to Cádiz-like and French revolutionary despotism. Hence the exceptional un-modernity - not anti-modernity, because even the anti-modern contains the modern - of the Spanish Counter-Enlightenment, which Ceballos had announced early with his late preference for the ancients. The irony was that, in insisting that devotion ensures individual well-being as much as cosmic harmony, this un-modernity resembled paganism - of the kind that would have drawn the frowns of the Inquisitorial tribunal.

\section{Notes}

I I am grateful to the reviewers of the International Journal for History, Culture and Modernity for their comments on a previous draft of this paper.

2 See Antonio Morales Moya, 'La nación católica de Menéndez Pelayo', Historia de la nación y del nacionalismo español, Antonio Morales Moya, Juan Pablo Fusi Aizpurúa and Andrés de Blas Guerrero (eds) (n.p., 2013) $502-24$, at 503 .

3 'Rancio' or 'rancid' was the derogatory adjective that liberals used to describe conservatives.

4 A nationalist term referring to pure or full-blooded Spanish.

5 Herrero, Los orígenes del pensamiento reaccionario español (Madrid, I973; 2nd ed.) 374 . 
6 Ibid., 28I.

7 Josep Escrig Rosa, 'Pasión racional, razón apasionada. El primer antiliberalismo reaccionario en España', Ayer I I I:3 (20 I8) I35-6I, at I37.

8 Julio Herrera, Serviles! El grupo reaccionario de las Cortes de Cádiz (Málaga, 2007) 234.

9 On Burke as a Counter-Enlightenment figure, see Graeme Garrard, CounterEnlightenments: From the Eighteenth Century to the Present (Milton Park and New York, 2006), passim.

Io See José Álvarez Junco, 'Identidad heredada y construcción nacional. Algunas propuestas sobre el caso español, del Antiguo Régimen a la Revolución Liberal', Historia y política: Ideas, procesos y movimientos sociales, special issue Estado e identidades nacionales en la España contemporánea, 2 (I999) I23-46; 'La difícil nacionalización de la derecha española en la primera mitad del siglo XIX', Hispania, 6r:3, 209 (200I) 83I-58; 'La nación posimperial: España y su laberinto identitario', Historia Mexicana, 53:2 (2003) 447-68; 'El conservadurismo español, entre religión y nación', Del territorio a la nación: identidades territoriales y construcción nacional (Madrid, 2006) 39-64; 'La guerra de la independencia y el surgimiento de España como nación', Claves de razón práctica, I92 (2009) 4-I3; 'Catolicismo e identidad nacional en la España del siglo XIX', Laicidad y libertades: escritos jurídicos I4 (20I4) I53-75.

I I Andoni Artola Renedo and Antonio Calvo Maturana, 'Declinaciones de la reacción eclesiástica contra la Revolución francesa en España (I789I 808)', Hispania, 77:256 (2017) 437-69. I am grateful to Francisco Javier Ramón Solans for bringing this article to my attention.

I2 Darrin McMahon, Enemies of the Enlightenment: The French CounterEnlightenment and the Making of Modernity (Oxford, 200I) I 5.

I3 Also spelt Zevallos, Cevallos and Zeballos.

I 4 Ceballos, La falsa filosofía, o el ateísmo, deísmo, materialismo, y demás nuevas sectas convencidas de crimen de estado contra los Soberanos y sus Regalías, contra los Magistrados y Potestades legítimas 6 vols (Madrid, I775; 2nd ed.) I:3.

I5 See Menéndez Pelayo, Historia de los heterodoxos españoles (Madrid, I978), 5:250 I-6.

I6 See Ricardo Robledo, 'El padre Cevallos "humilde capellán” de Godoy? El plan de universidades de I796', https:/gredos.usal.es/ jspui/bitstream/I0366/I 2 I 304/I /DEHE_RobledoHernandezRicardo_ ElPadreCevallos.pdf (accessed I7 December 2017) I7. 
I7 https://commons.wikimedia.org/wiki/File:Fernando_de_Ceballos._La_ falsa_filosof\%C3\%ADa.png (accessed 28 May 20I9).

I 8 Public Finances.

I9 Dale Van Kley, Reform Catholicism and the International Suppression of the Jesuits (New Haven, London, 2018) 24.

20 On Spanish Counter-Enlighteners' conversion to ultramontanism, see Renedo and Maturana, 'Declinaciones de la reacción eclesiástica'.

2 I El juicio final de Voltaire con su historia civil y literaria y el resultado de su filosofía, por el viagero de Lemnos, según la oyó y copió de los filósofos infernales en los abismos de Antiparos ( 1856) 201.

22 La falsa filosofía, 5:309-Io.

23 No information survives on Juan Antonio de Las Casas. The name was probably a pseudonym, given both Dei delitti's inclusion in the Index librorum prohibitorum and the connotations of social justice that the name of Las Casas evokes. Alessandro Verri (I74I-I8I6) identifies Juan Alves or Juan Álvarez as Dei delitti's real translator, but no information may be found on him either. See Gonzalo Quinto Olivares, 'Beccaria y el Iluminismo italiano en la cultura jurídica hispana', Metáfora de la crueldad: la pena capital de Cesare Beccaria al tiempo presente, Luis Arroyo Zapatero, Rafael Estrada Michel, Adán Nieto Martín and Agustina Alvarado (eds) (Cuenca, 2016) 62n.

24 Robledo, 'El padre Cevallos', 3.

25 Ibid., I. Renedo and Maturana indicate I 782 as the date of the silencing: 'Declinaciones de la reacción eclesiástica', 442.

26 Ibid., 445.

27 La falsa filosofía, I: I20.

28 Ibid., I: I I9.

29 See the (unpaginated) dedicatio to Campomanes.

30 Ceballos, La falsa filosofía, i:228.

3 I Ibid., I38.

32 In Ephesians 2:I9: 'Now, therefore, you are no longer strangers and foreigners, but fellow citizens with the saints and members of the household of God' (NKJV).

33 Ceballos, La falsa filosofía, I:277.

34 Ibid., 229.

35 Ibid., I 17.

36 On Ceballos' letters to Godoy, see Robledo, 'El padre Cevallos'.

37 Dale Van Kley, Reform Catholicism and the International Suppression of the Jesuits in Enlightenment Europe (New Haven and London, 2018) I66. 
38 Ceballos, La falsa filosofía, 5:20I.

39 Ibid., I:289.

40 Ibid., 338.

4I Ibid., I75.

42 Richard Herr, The Eighteenth-Century Revolution in Spain (Princeton, I958) 2 I 4.

43 Ceballos, La falsa filosofía, I:79.

44 Herr, The Eighteenth-Century Revolution in Spain, 2 I 6.

45 https://hdl.handle.net/2027/ucm.53 I94468I6 (accessed 28 May 20I9).

46 Valcarce, Los desengaños filosóficos, que en obsequio de la verdad de la religión y de la patria da al público el doctor Don Vicente Fernandez. Valcarce, 4 vols (Madrid, I787-I797) 4:iv.

47 Valcarce, Los desengaños filosóficos 4:v-vi.

48 Ibid., 4:vii.

49 Ibid., 4 :ix.

50 Ibid., 4:I48.

5I On Rousseau as founder of Counter-Enlightenment, see Graeme Garrard, Rousseau's Counter-Enlightenment: A Republican Critique of the Philosophes (Albany NY, 2003).

52 Herrero, Los orígenes del pensamiento reaccionario español, I53.

53 https://commons.wikimedia.org/wiki/File:Herv\%C3\%AIs.jpg (accessed 28 May 20I9).

54 This was Antonio María Ponce de León Dávila y Carrillo de Albornoz, who would preside the Junta de Jaén during the Peninsular War and become counselor to Fernando VII.

55 Herrero, Los orígenes del pensamiento reaccionario español, I53.

56 Ibid., I 54 .

57 Ibid., I57.

58 By José Ignacio Moreno Iturralde (Madrid).

59 Lorenzo Hervás y Panduro, Causas de la Revolución de Francia en el año I789, y medios de que se han valido para efectuarla los enemigos de la religión y del estado 2 vols (Madrid, I807) I:I9.

60 Ibid., 29.

6 I Ibid., 25.

62 Ibid., 23.

63 Ibid., I20-I.

64 Ibid., 309.

65 Ibid., 20 I. 
66 Ibid., 206.

67 See Eastman, Preaching Spanish Nationalism across the Hispanic Atlantic, I759-I823 (Baton Rouge, 20I2) and 'Las identidades nacionales en el marco de la esfera pública católica: España y Nueva España durante las guerras de independencia', in Jaime E. Rodríguez O. (ed.), Las nuevas naciones: España y México I800-I850 (Madrid, 2008) 75-98.

68 Armenteros, The French Idea of History (Cornell, 20 I I) 38-42.

69 Herrera, Serviles!, 26o. The following three paragraphs draw on this work.

70 Francisco Alvarado, Cartas críticas que escribió el Rmo. Padre Maestro Fr. Francisco Alvarado, del Orden de Predicadores, o sea El Filósofo Rancio, 5 vols (Madrid, I824) I:6.

7 I Ibid., 7.

72 Ibid., Io.

73 Alvarado, Cartas críticas, 3:8.

74 Junco, 'Catolicismo e identidad nacional en la España del siglo XIX', I6o.

75 Alvarado, Cartas, 2:383-4. Cited in Junco, 'La difícil nacionalización', 834 .

76 Literally, 'the Frenchified ones', a derogatory term used to designate those Spaniards who collaborated with the invader.

77 Junco, 'La guerra de la independencia', I I.

78 Ibid., 7 .

79 Junco, 'Identidad heredada y construcción nacional', I44.

80 Alvarado, Cartas críticas, I:2 I 2.

8 I See Junco, 'La guerra de la independencia' I I-I 2.

82 Alvarado, Cartas críticas, I:I4.

83 Ibid., I:42.

84 Ibid., 40.

85 Ibid., 4I.

86 Ibid., I $85-6$.

87 Ibid., 3:3.

88 Junco, 'El conservadurismo español', 50.

89 https://commons.wikimedia.org/wiki/File:An\% $3 \%$ B3nimo-rafael_ de_v\%C3\%A9lez.jpg (accessed 28 May 20I9).

90 Vélez, Preservativo contra la irreligión, ó Los planes de la filosofía contra la religión y el estado, realizados por la Francia para subyugar a la Europa, seguidos por Napoleón en la conquista de España, y dados a luz por algunos de nuestros sabios en perjuicio de nuestra patria (Madrid, I 8 I 3 ; 4th ed.) 7 . 
9I Vélez, Apología del altar y del trono, ó Historia de las reformas hechas en España en tiempo de las llamadas Cortes; e impugnación de algunas doctrinas publicadas en la Constitución, diarios y otros escritos contra la religión y el estado, 2 vols (Madrid, I825) I:28.

92 Ibid., 27.

93 Vélez, Preservativo contra la irreligión, 3.

94 On the religion-state rapport, see Josep Escrig Rosa and Encarna García Monerris, 'Constitución y verdad. La controversia entre Rafael de Vélez y Joaquín Lorenzo Villanueva a propósito de la Apología del Trono', Hispania, 77:256 (2017) 497-525.

95 See Josep Escrig Rosa, “'Las naciones han existido antes que los reyes?” Monarquía y nación antiliberal en Fray Rafael de Vélez’, unpublished manuscript.

96 Vélez, Preservativo contra la irreligión, ıo6.

97 Ibid., Io.

98 Vélez, Apología del altar y del trono, I:8I.

99 Ibid., 2:I44.

IOO Ibid., I:2.

IO I Exceedingly little is known about Francisco Isnardi, chiefly remembered for writing and signing Venezuela's Declaration of Independence. Herrero calls him José Isnandy, but Asier Solana, a researcher on the history of Ceuta's press, identifies him as Francisco Inardi. Nothing is known of him after his dispute with Vélez, and no copies survive of El liberal africano. See Asier Solana, 'Los periodistas se han adaptado a lo que han podido escribir', El Faro de Ceuta. Cultura y Tradiciones, Noticias (2010), https://elfarodeceuta.es/los-periodistas-se-han-adaptado-a-lo-que-hanpodido-escribir/ (accessed 17 December 2017).

I02 On the polemic between Vélez, the Cortes and Ceuta's political authorities in biographical context, see Josep Escrig Rosa, "'La política del siglo no es para la casa de Dios": Fray Rafael de Vélez en tiempos de liberalismo y revolución', Tiempo de política, tiempo de Constitución: la monarquía hispánica entre la revolución y la reacción (I780-1840), Ivana Frasquet Miguel and Encarna García Monerris (eds), Revista de estudios políticos, I82 (2018) 239-262.

I03 The phrase is Vicente Cárcel's. See his Historia de la Iglesia en la España contemporánea (siglos XIX y XX) (Madrid, 2002) I I 9.

I04 See on this point Charles Esdaile, The Peninsular War: A New History (New York, 2003). 
I05 See Dale Van Kley, 'Civic Humanism in Clerical Garb: Gallican Memories of the Early Church and the Project of Primitivist Reform I7I9-I79I', Past \& Present, 200:I (2008) 77-I 20, at I I9.

\section{About the Author}

Carolina Armenteros (PhD Cantab.) is a Researcher at the Pontificia Universidad Católica Madre y Maestra and an intellectual historian of modern Europe. She is interested in gender theory, early conservatism, religious history, eighteenth-century Orientalism, early anthropology and the foundations of sociology. Her monograph The French Idea of History: Joseph de Maistre and his Heirs (Cornell, 20I I) has been translated into French and Spanish, with a pocket edition appearing with Classiques Garnier in 2018. Carolina has likewise co-edited Historicising the French Revolution (Cambridge Scholars, 2008), Joseph de Maistre and his European Readers (Brill, 20II), Joseph de Maistre and the Legacy of Enlightenment (SVEC, 20I I), and The New enfant du siècle: Joseph de Maistre as a Writer (St Andrews, 20IO). At present, she is co-editing the proceedings of the conference 'Monarchy and Modernity since I500' that she organized at the University of Cambridge in 2019, and pursuing research projects on royalist views of history, missionary contributions to the social sciences and the gender politics of Jean-Jacques Rousseau (I7I 2-I776). E-mail: c.armenteros8 I @gmail.com. 